Guest Editorial, part of a Special Feature on Resilience and Vulnerability of Arid and Semi-Arid Social Ecological Systems

\title{
Assessing Vulnerability to Climate Change in Dryland Livelihood Systems: Conceptual Challenges and Interdisciplinary Solutions
}

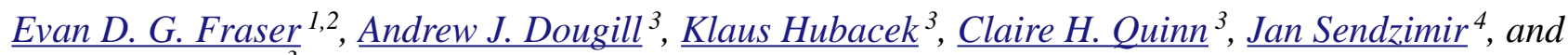 \\ Mette Termansen $^{3}$
}

\begin{abstract}
Over $40 \%$ of the earth's land surface are drylands that are home to approximately 2.5 billion people. Livelihood sustainability in drylands is threatened by a complex and interrelated range of social, economic, political, and environmental changes that present significant challenges to researchers, policy makers, and, above all, rural land users. Dynamic ecological and environmental change models suggest that climate change induced drought events may push dryland systems to cross biophysical thresholds, causing a long-term drop in agricultural productivity. Therefore, research is needed to explore how development strategies and other socioeconomic changes help livelihoods become more resilient and robust at a time of growing climatic risk and uncertainty. As a result, the overarching goal of this special feature is to conduct a structured comparison of how livelihood systems in different dryland regions are affected by drought, thereby making methodological, empirical, and theoretical contributions to our understanding of how these types of social-ecological systems may be vulnerable to climate change. In introducing these issues, the purpose of this editorial is to provide an overview of the two main intellectual challenges of this work, namely: (1) how to conceptualize vulnerability to climate change in coupled social-ecological systems; and (2) the methodological challenges of anticipating trends in vulnerability in dynamic environments.
\end{abstract}

Key Words: adaptability; climate change; drought; food security; livelihoods; vulnerability

\section{INTRODUCTION}

Over $40 \%$ of the earth's land surface are drylands, encompassing arid, semiarid, and dry subhumid climatic zones that are home to approximately 2.5 billion people (Millennium Ecosystem Assessment 2005). Livelihood sustainability in these regions is threatened by a complex and interrelated range of social, economic, political, and environmental changes that present significant challenges to researchers, policy makers, and, above all, rural land users (Reynolds et al. 2007). Concerns over dryland degradation, often termed desertification, have been widely reported since the Sahelian droughts of the late 1960 s and the global policy response to this problem is formalized through the UN Convention to Combat Desertification (UNCCD). It is increasingly recognized that changes in soil fertility and ecosystem processes are the most pressing forms of dryland degradation (Stocking 2003) and that social and institutional factors remain the most frequent drivers (Stringer 2008). Key institutional and socioeconomic changes include the breakdown of traditional land tenure systems (Toulmin and Quan 2000), a reduced ability to move livestock across the landscape (Lane 1998), and shifts toward cash cropping a narrow range of commodities (Whiteside 1998).

Dynamic, often termed nonequilibrium, ecological, and environmental change models (e.g., Dougill et al. 1999, Joubert et al. 2008) suggest that climate change-induced drought events may exacerbate this problem, pushing dryland systems to cross biophysical thresholds, causing a long-term drop in agricultural productivity. The scientific consensus with regard to future climate change is that the proportion of dryland areas affected by droughts is 
likely to increase (IPCC 2007a). Sub-Saharan African drylands have been highlighted as particularly vulnerable because of their low adaptive capacity and sensitivity to the projected changes (Callaway 2004, IPCC 2007b). However, a similar combination of climate and socioeconomic pressures are being observed in North Africa (Christensen et al. 2007, Thomas 2008), Asia (Lioubimtseva et al. 2005, Cruz et al. 2007), and Latin America (Eakin and Wehbe 2009). Considerable uncertainty, however, remains about how future climatic changes will affect drylands (Sitch et al. 2007) and it is imperative that new and interdisciplinary research agendas are developed focusing on livelihood security in these dynamic, complex, and risk-prone environments (Reed et al. 2008). Specifically, research is needed to explore how development strategies and other socioeconomic changes can help livelihoods to become more resilient and robust at a time of growing climatic risk and uncertainty (Thompson and Scoones 2009).

The overarching goal of this special feature is to conduct a structured comparison of how the livelihood systems in different dryland regions are changing in their vulnerability to climate change. In doing so, this collection of papers has three objectives. The first objective is to make an empirical contribution to our understanding of how these types of social-ecological systems are vulnerable to climate change. The second objective is to make a theoretical contribution to climate change effects research by testing and refining an analytical framework through which to assess vulnerability. The third objective is to provide methodological insight into the strengths and weaknesses of using tools from different disciplines and the ways they can best be combined for more accurate assessments of dryland system vulnerability. In introducing these issues, the purpose of this opening editorial is also threefold: (1) to summarize the literature on vulnerability to climate change in coupled social-ecological systems and present the conceptual framework used in this special feature to comparatively assess vulnerability across the case studies; (2) to discuss the methodological challenges of anticipating trends in vulnerability in dynamic environments and present the methodological framework used by the case studies; and (3) to provide a short précis of the case studies presented in this special feature.

\section{CONCEPTUALIZING VULNERABILITY TO CLIMATE CHANGE IN COUPLED SOCIAL-ECOLOGICAL SYSTEMS}

\section{Background literature}

The first challenge in presenting a consistent analysis of the different case studies was to establish a common theoretical understanding of vulnerability. The literature on vulnerability is a vast corpus of material spanning a wide range of disciplines including disaster management, risk analysis, engineering, ecology, and sociology (Adger 2006). This body of literature also includes a range of case studies such as preparedness to tropical storms (Tompkins 2005), drought coping strategies (Roncoli et al. 2001), and the effects of sea level rise (Adger 1999). Taken together, this research suggests that the social and ecological context in which climatic problems occur is likely to be as important, if not more so, than the climatic shock itself (Watts and Bohle 1993, Turner et al. 2003, Ericksen 2008). This observation has been confirmed by qualitative historic case studies that show relatively small environmental problems can cause significant consequences depending on socioeconomic constraints (Comenetz and Caviedes 2002, Fraser 2003), as well as by quantitative work on the socioeconomic factors that make grain harvests sensitive to rainfall anomalies (Fraser et al. 2008, Simelton et al. 2009).

More specifically, effort has been invested in modeling crop production under different climate scenarios (e.g., Challinor et al. 2009). It is clear from this work that farm management, e.g., choice of crops, along with environmental characteristics, for example, soil fertility, will have a large influence on whether or not weather-related shocks affect yields (Smit and Skinner 2002, Challinor 2009). One implication of this work is that different agroecosystems react differently to similar climatic problems. Therefore, for this special feature, each vulnerability assessment includes an analysis of the agroecological factors effecting the farming system vulnerability. This involves exploring the ability of specific dryland agroecosystems to tolerate climatic extremes, notably droughts, and/or the ability of these ecosystems to rebound following a climatic extreme so as to avoid famine-related deaths.

Economic modelers have also contributed to this field by showing that even rural livelihoods, which rely on agriculture for income as well as subsistence, 
depend on much more than just biophysical factors. For example, Mendelsohn (2007) finds that $39 \%$ of the variations in average crop failure in the U.S. can be explained by variations in climate and soil implying that other factors, which may include socioeconomic and institutional/political conditions, account for the $61 \%$ of crop failure. Although these results are based on North American data, they broadly confirm work on livelihood diversification, land management, and biodiversity done in Africa (Block and Webb 2001, Unruh 2001). To account for these other factors, Sen's work $(1983,2000)$ on food security, which focuses on "freedom" and "capability" at the household scale, is particularly useful. Sen recognizes that if households have access to a range of different resources then they will have greater capacity to adapt to a problem. For example, a rural household with extensive friends or other social relations may be able to maintain productivity without outside institutional help during a drought because they may be better able to move cattle between regions to obtain fodder (Reed et al. 2008). Sen's work, which provides a theoretical foundation for understanding such capabilities, has given rise to the "sustainable livelihoods approach," a set of methodological tools that are used to explore how households deploy "capital assets" to maintain livelihoods during shocks (Scoones 1998). Capital assets include: social capital, i.e., networks of friends and relations; human capital, i.e., a person's health and education; financial capital, i.e., income or savings; physical capital, i.e., the built infrastructure; and natural capital, i.e., ecological features such as soil quality or forests (Bebbington 1999). In addition, a sustainable livelihood analysis also examines broader contextual questions such as the household's exposure to shocks, e.g., floods or droughts, and trends such as environmental or population change, as well as chronic disease threats. Therefore, to build on this literature, each vulnerability assessment in this special feature includes an explicit evaluation of the socioeconomic context based on a sustainable livelihoods approach.

Finally, the literature also suggests that researchers interested in vulnerability must assess institutional processes. For example, de Waal (1997) provides a critical exploration of the role of the international community in providing famine relief whereas Ostrom and others explore the role of institutions at a more local scale (Ostrom et al. 1999, Ostrom 2001). The importance of institutions in determining vulnerability to climate change was illustrated in 1991-1993 when an apocalyptic drought in southern Africa caused grain yields in ten states to drop 56\% below normal years and 17-20 million people were exposed to starvation (Green 1993). Despite the magnitude of the problem, a combination of national and international policy helped avert disease and death in countries with functioning governments (Green 1993). Therefore, understanding whether livelihoods are vulnerable to climate change also involves assessing the institutions that are working in society that allow for a collective response to a problem (Scott 2001). Consequently, each vulnerability assessment in this special feature also involves an institutional dimension that includes exploring what groups within a society have power and are able to mobilize political attention.

\section{Proposed framework}

We draw from these literatures that there are three distinct but overlapping components that must be included in any assessment of the vulnerability of a social-ecological system to climate change. These are: (1) an assessment of the agroecosystem that provides the livelihoods, thus providing insight into the ability of each agroecosystem to remain productive or to rebound following a drought; (2) a sustainable livelihoods-based evaluation of the socioeconomic affluence of different groups within the livelihood system, thus providing insight into those groups that may not have the capacity to adapt themselves; and (3) an exploration of the institutional capability, thus providing insight into which regions have the potential to mobilize effective relief in a crisis.

These three factors can be heuristically depicted as a three dimensional space diagram in which each of these factors represents one dimension (Fraser 2007; Fig. 1). When used to assess vulnerability in different cases, information would need to be collected for each dimension. If data, for instance, show that the agroecosystem is becoming less able to remain productive during an environmental problem, that households are losing socioeconomic assets, and that institutions have a diminishing capacity to respond to a crisis, then this could be plotted into this vulnerability space as a trend toward the top, back, and right corner of the figure (corner 8, Fig. 1). Such a trend would imply that the livelihood system within the case study was becoming more vulnerable to climate change and 
that a comparatively small environmental problem may have a larger effect on livelihoods.

Although this model provides a heuristic framework to visualize changes over time and to allow a rough comparison between cases, it is important to note that how each of these three key components is assessed will depend on the scale of the system being investigated as well as the socioeconomic and ecological context. For example, in one region, the topography of the farmer's fields may be critical to understanding the effects of storms. In another region, on-farm livelihood diversity may be more relevant. Also, the effect of policies, demographic trends, cultural beliefs, ideologies, or market forces on these three factors will depend on local context. For example, there is a considerable literature that shows the effect that economic growth and economic globalization have on farm agrodiversity depends on non-farm issues such as access to markets and available labor pools (Fraser 2006). As such, the specific indicators used to assess each of these components need to be grounded in local conditions.

The fact that vulnerability needs to be assessed through locally grounded variables highlights a tension that runs through the vulnerability literature. On the one hand, scholars are aware that how you assess vulnerability needs to vary across both space and time. However, this does not mean that there are not general lessons to be learned. Policy also needs some common platform with which to compare regions and assess changes over time. The framework presented in figure 1 is designed, therefore, to provide a heuristic for spatial and temporal comparisons while still requiring more detailed local analysis to highlight locally important contextual issues.

\section{METHODOLOGICAL APPROACHES TO ANTICIPATE TRENDS IN VULNERABILITY}

\section{Methodological challenges}

Another intellectual challenge in conducting the comparative analysis of different cases was to find a consistent yet flexible set of steps to be used in each study. The academic literature is full of examples of quantitative models being used to understand systems and to predict how climatic changes may affect agricultural production and livelihoods (Lobell et al. 2008). Trying to understand complex social-ecological phenomena using quantitative tools has a long intellectual tradition and dates back at least to Thomas Malthus. More recently, mathematical models were used in early attempts to anticipate the Earth's future in light of rising population, overuse of resources, and pollution (Meadows and Club of Rome 1972).

However, many forecasts of complex socialecological systems made over the past 20 years have been proven wrong (Sterman 2002). One possible reason for this is that mathematical modeling lends itself more readily to modeling biophysical relations that are comparatively simple and more predictable than socioeconomic relations. The chapter on food and fiber by Working Group II of IPCC's fourth assessment report illustrates this tension (Easterling et al. 2007). It provides an excellent survey of how crops respond to moisture stress, carbon dioxide fertilization, and elevated temperatures. However, it is much less complete in terms of the people who produce these crops. The section on adaptive capacity, for example, is quite short and simply discusses how the effect of climate change on food production will depend on local socioeconomic context. The actual projections made in the chapter, however, do not include social or economic considerations. This has serious implications because it is these human-less projections that provide much of the evidence for climate change policy advice. This problem was highlighted by Hulme (2007:5) who stated, "The construction of narratives around global warming remain strongly tied to roots within the natural sciences ... which claims both global reach and universal authority."

What Hulme refers to as a "global reach and universal authority" of the natural sciences has given the modeling community, and the atmospheric modelers in particular, more power when it comes to translating their research into policy advice. These challenges to mathematical modeling approaches need to be seen in a broader academic context of postmodernism in the social sciences. For the last 40 years, there has been a significant emphasis among many sociologists and anthropologists on discourse theory and how an individual's position or background shapes their perceptions of everything from the landscapes they find aesthetically pleasing (Suckall et al. 2009) to their perceptions of risks that they face (Tansey and O'Riordan 1999). One conclusion of this work is that scientific pursuits are never as objective or 
Fig. 1. Generic vulnerability framework made up of three dimensions the literature suggests are important in assessing vulnerability: (1) agroecosystem resilience that measures the extent to which the agroecosystem can tolerate climatic shocks and remain productive; (2) socioeconomic affluence that measures the extent to which households will have access to the assets needed to maintain livelihoods in the event of an environmental shock; and (3) institutional capacity that measures the extent to which institutions in society will provide effective crisis relief.

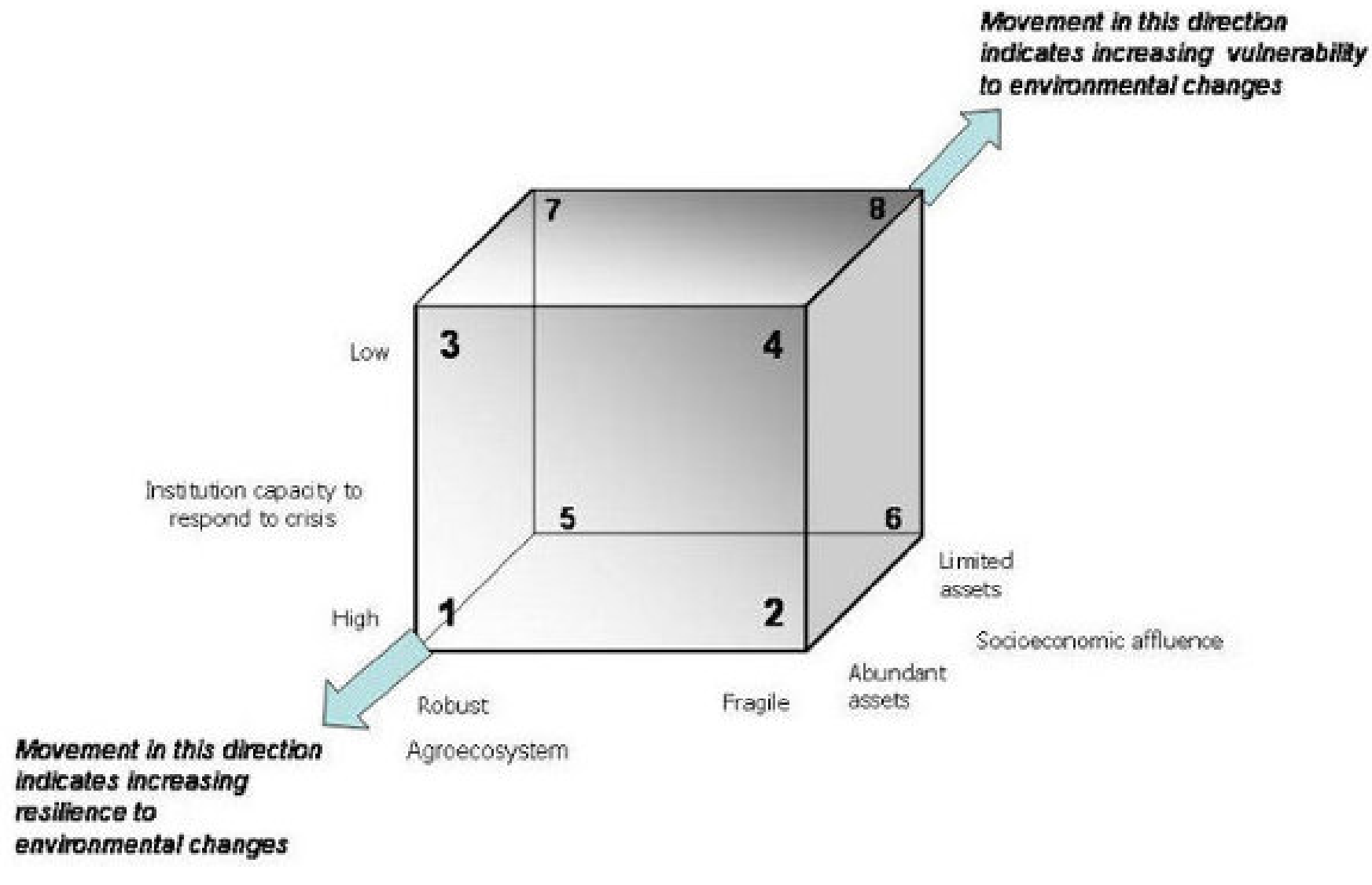

impartial as may be claimed, but rather are socially constructed (Wynne 1992). The message that many social scientists take from this is that we must be highly critical of any theory or model because they may reveal more about the author of the theory than the real world. As a result, many social scientists are skeptical of empirical methods and have rejected the mathematical tools common in natural sciences.

A different type of modeling has emerged that tries to address some of these concerns. Called mediated modeling, it is a cluster of approaches that tries to capture complex system dynamics by drawing on a range of different types of input, including qualitative stakeholder and expert opinions, to help management and policy making. Rather than attempting to reduce uncertainty through ever more accurate prediction, mediated modeling attempts to incorporate potential feedbacks and different assumptions of scientists or stakeholders. Sometimes this approach also uses formal computer models to challenge the implicit or 'mental models' of policy makers (Lane 2007). The goal is for a range of experts, policy makers, or other stakeholders to work together and uncover complex relations within a dynamic system. This allows for the creation of a model of the system that can be tested to provoke a re-examination of primary assumptions, at which point the underlying conceptual and/or mental models are more easily discovered. 
Mediated approaches to create system dynamics models have been applied in a variety of group model building exercises (e.g., Van den Belt 2004, Dougill et al. 2006). Such examples provide a series of generic steps that help a group of people, both researchers and local stakeholders/land managers, to first develop a common conceptual model of how a dynamic system such as a livelihoods system works, and then provide guidance on how to formalize this conceptual model into a deterministic computer model (Volpe and Voss 2005). Each approach generally involves bringing a team of people together to create a narrative or story of how a system works. Narratives are then turned into conceptual models or flow charts, sometimes called causal loop diagrams or mental maps, of the system that is of concern. This conceptual modeling phase exposes key relationships, makes feedbacks explicit, and helps identify where there are key gaps in the knowledge of the important relations. Conceptual models also help to show where there are key drivers that may affect overall system functioning and can help to identify where potential thresholds or tipping points occur that are likely to trigger rapid system changes.

A conceptual model, built through such a group exercise, imperfectly reflects and synthesizes the underlying mental models of the participants. Developing conceptual models, therefore, is a useful exercise in that it enables group problem solving and produces heuristic devices that incorporate a variety of different types of information. Conceptual models have been used to point the way toward future research and can help stakeholders articulate hypotheses to be tested. Generally speaking, this is the approach used through the "soft systems methodology" that guides groups to analyze and solve management problems (Checkland and Winter 2006). Many proponents of this methodology, especially those from sociological, anthropological, and development studies traditions, stop at the stage of a diagrammatic conceptual model rather than exploring additional information that may be gained by quantifying relationships within the models. Others argue that although all models are simplifications, results from running formal model simulations can still be useful for exploring the dynamic consequences of what is assumed at the conceptual modeling stage (Sterman 2002, Epstein 2008).

Despite the concerns about turning mental models into mathematical models, a number of scholars argue that using mathematics to create different simulations of the future is necessary. One reason for this is that in the absence of formal quantification, simple causal loop diagrams can be misleading because they obscure the "stock and flow structures" that drive complex systems. Stock and flow structures occur where a stock of a resource changes over time. For example, this might be land that is converted from forest to tilled agricultural land that then turns into degraded land. This sort of dynamic is poorly captured through causal loop diagrams, and the nature of stocks and flows makes it necessary to express relations formally in order to run simulations to observe how stocks may change under different scenarios. Therefore, Richardson (1986) suggests that people wishing to use system dynamics to analyze complex phenomena should either avoid causal loop diagrams entirely or only use them to accompany expository writing that can be elaborated on through mathematical simulations. Similarly, Homer and Oliva (2001) argue that one cannot draw reliable inferences from complex causal maps without formal simulation and that not defining the relationships between components means that we forego attempts to identify connections often unseen by stakeholders. This is important since neurological and psychological studies show the human brain is ill-equipped to comprehend complex connections or to accurately predict thresholds, emergent properties, or feedbacks (Sterman 1992, 2002).

\section{Methodological framework}

This brief discussion on dynamic system modeling highlights two things. First, there is a growing awareness that dynamic systems modeling is useful as a way of creating a rich picture that brings together a range of information to describe a problem. Second, there is disagreement over whether to use system dynamics as a qualitative or quantitative tool. In many important ways, this disagreement is related to the value of causal loop diagrams as a stand-alone policy tool or whether they need to be accompanied by formal mathematical simulations. A compromise is offered by Wolstenholme (1999:42) who states that although:

Formal, quantitative models are essential for understanding the dynamics of complex systems, the need for quantification is 
relative and depends on the purpose of analysis, which, in turn, is related to the methods used and the audience addressed. ... [The] true power of system dynamics to address problem solving lies in a judicious blend and intertwining of both qualitative and quantitative ideas, aimed at addressing as broad an audience as possible whilst remaining sufficiently rigorous to be useful.

In practical terms, Wolstenholme is proposing that key relations within a causal loop diagram should be formally expressed and calibrated with actual data. Where this is not possible, relations can be estimated using expert opinion to create a heuristic learning device that can be used to create simulations and potentially identify uncertainty in current understanding of key relationships. The results of this sort of model are not prescriptive and do not claim to predict the future. Although such attempts are still fraught with conceptual, philosophical, and methodological challenges, this approach offers a way of using mathematical simulation as a learning device. In a world of imperfect knowledge and uncertainty, dynamic systems modeling offers a rapid, transparent, and systematic approach to capture and use diverse knowledge to better understand how complex systems work.

The articles in this special feature will not resolve these discussions. Rather, we use a combination of mediated dynamic systems modeling approaches to explore some of the tensions. More specifically, we synthesized approaches into four generic methodological steps and then use the case studies to explore different elements within these four steps:

1. To use expert opinion and published socioeconomic and environmental data to establish a background narrative that describes the livelihood system and its social, institutional, and ecological context;

2. To refine the narrative and establish a conceptual model of the livelihood system focusing on the three dimensions of vulnerability (Fig. 1);

3. To conduct a three-part qualitative vulnerability analysis of the livelihood system in the case study region to show how the three dimensions of vulnerability, i.e., agroecological, household assets, and institutional factors, have changed through time;

4. To conduct a quantitative vulnerability analysis in which key relations in the conceptual model are expressed numerically. This enables different policy simulations that help establish hypotheses about which elements of the system would be most influential in changing future vulnerability.

Each case study in this special feature emphasizes different aspects of these steps. Some focus on the critical construction of the narrative (Crane 2010, Sallu et al. 2010). Others focus on the construction of the conceptual model and the qualitative vulnerability analysis (Dong et al. 2011, Li and Huntsinger 2011, Quinn et al. 2011, Ravera et al. 2011, Sendzimir et al. 2011). Only two (Dougill et al. 2010, Máñez Costa et al. 2011) use formal modeling to create future scenarios. In doing this, our goal is to shed some light onto the strengths and weaknesses of using these different approaches and to reflect on these in the closing editorial.

\section{OVERVIEW OF CASE STUDIES}

Two of the case studies, by Crane (2010) and Sallu et al. (2010), are the most rooted in the qualitative social science tradition. Crane describes the relevance of ideological aspects of culture, especially values and systems of meaning, to vulnerability, resilience, and adaptation. In particular, this article shows how cultural ideologies shape experience of, and adaptive responses to, climate change. This is based on research in central Mali where subsistence niches have historically been closely linked with distinct ethnicities. Sallu et al. explore the resilience and vulnerability of livelihoods in two remote communities in rural Botswana over the last 30 years and draw on field data sources that include oral histories, livelihood surveys, ecological surveys, and documented evidence of environmental, socioeconomic, and institutional change. This paper identifies a broad range of activities that combine to create a range of different household livelihood portfolios and uses this information to assess how these livelihood activities have changed over time.

Four case studies emphasize conceptual modeling to explore vulnerability to climate change. Quinn et al. (2011) investigate how local communities cope 
with and adapt to multiple stresses, including water scarcity, in rural semiarid South Africa. These authors construct system diagrams and narratives to examine the relationships and interactions among ecological conditions, institutions at different scales, and local communities to understand local adaptive capacity. Li and Huntsinger (2011) assess how changes in land tenure have reduced pastoralists' ability to benefit from rangelands and how this has affected their responses to adverse climatic events. Ravera et al. (2011) assess the vulnerability caused by changes of agropastoral food systems in the semiarid mountain region in northern Nicaragua, an area that has displayed ecological and social resilience to environmental instabilities. Sendzimir et al. (2011) examine the causal mechanisms that link ecological, economic, and socio-political processes, both within and across scales, in the surprising regreening of the Sahel in south-central Niger over the past two decades. Both the multilayered structure and its dynamism challenge understanding of this complex adaptive system in which national and international policies, along with international and regional NGOs, supported farmers in efforts to increase climatic resilience in this livelihood system.

Two case studies emphasize the creation of formal future scenarios by describing relations in the conceptual models using a formal mathematical tool. Máñez Costa et al. (2011) focus on one of the poorest regions in the EU, a region of Southern Portugal where the traditional farming system is rainfed and combines cattle raising with cultivation of cereals. During the 20th century, the intensification of cereal cultivation and later the population exodus have radically changed this landscape and affected its capacity to cope with the threats of climate change. Dougill et al. (2010) use causal loop diagrams to simulate the dynamics of key pastoral system variables for the Kalahari of Botswana. This allows the authors to establish basic future scenarios that lead to a series of hypotheses, including that poverty reduction may be more effective at reducing drought vulnerability than policies targeting environmental best management. Last, in the closing editorial, we compare all the case studies, reflect on commonalities and differences, and evaluate the vulnerability framework applied as well as the integration of different methods.
Responses to this article can be read online at:

http://www.ecologyandsociety.org/voll6/iss3/art3/responses/

\section{Acknowledgments:}

Thanks to Maria Máñez Costa, Mark Reed, Suzy Sallu, Elisabeth Simelton, and Lindsay Stringer for constructive comments on drafts of this paper. This work was funded by the Economics and Social Research Council of the UK through a Rural Economy and Land Use Fellowship and the Centre for Climate Change Economics and Policy.

\section{LITERATURE CITED}

Adger, W. N. 1999. Social vulnerability to climate change and extremes in coastal Vietnam. World Development 27:249-269. http://dx.doi.org/10.1016/ S0305-750X(98)00136-3

Adger, W. N. 2006. Vulnerability. Global Environmental Change 16:268-281. http://dx.doi.o rg/10.1016/j.gloenvcha.2006.02.006

Bebbington, A. 1999. Capitals and capabilities: a framework for analyzing peasant viability, rural livelihoods and poverty. World Development 27:2021-2044. http://dx.doi.org/10.1016/S0305-750X (99)00104-7

Block, S., and P. Webb. 2001. The dynamics of livelihood diversification in post-famine Ethiopia. Food Policy 26:333-350. http://dx.doi.org/10.1016/ S0306-9192(01)00015-X

Callaway, J. M. 2004. Adaptation benefits and costs: how important are they in the global policy picture and how can we estimate them? Global Environmental Change 14:273-284. http://dx.doi.o rg/doi:10.1016/j.gloenvcha.2004.04.002

Challinor, A. 2009. Towards the development of adaptation options using climate and crop yield forecasting at seasonal to multi-decadal timescales. Environmental Science and Policy 12:453-465. htt p://dx.doi.org/10.1016/j.envsci.2008.09.008

Challinor, A., F. Ewert, S. Arnold, E. Simelton, and E. Fraser. 2009. Crops and climate change: progress, trends, and challenges in simulating 
impacts and informing adaptation. Journal of Experimental Botany 60:2775-2789. http://dx.doi.o $\mathrm{rg} / 10.1093 / \mathrm{jxb} / \mathrm{erp062}$

Checkland, P., and M. Winter. 2006. Process and content: two ways of using SSM. Journal of the Operational Research Society 57:1435-1441. http:/ /dx.doi.org/10.1057/palgrave.jors.2602118

Christensen, J. H., B. Hewitson, A. Busuioc, A. Chen, X. Gao, I. Held, R. Jones, R. K. Kolli, W.-T. Kwon, R. Laprise, V. Magaña Rueda, L. Mearns, C. G. Menéndez, J. Räisänen, A. Rinke, A. Sarr, and P. Whetton. 2007. Regional climate projections. Chapter 11 in S. Solomon, D. Quin, M. Manning, Z. Chen, M. Marquis, K. B. Averyt, M. Tignor and H. L. Miller, editors. Climate change 2007: the physical science basis. Contribution of Working Group I to the Fourth Assessment Report of the Intergovernmental Panel on Climate Change. Cambridge University Press, Cambridge, UK.

Comenetz, J., and C. Caviedes. 2002. Climate variability, political crises, and historical population displacements in Ethiopia. Global Environmental Change Part B: Environmental Hazards 4:113-127. http://dx.doi.org/10.1016/j.hazards.2003.08.001

Crane, T. A. 2010. Of models and meanings: cultural resilience in social-ecological systems. Ecology and Society 15(4): 19. [online] URL: http: //www.ecologyandsociety.org/vol15/iss4/art19.

Cruz, R. V., H. Harasawa, M. Lal, S. Wu, Y. Anokhin, B. Punsalmaa, Y. Honda, M. Jafari, C. Li, and N. Huu Ninh. 2007. Asia. Pages 469-506. in M. L. Parry, O. F. Canziani, J. P. Palutikof, P. J. van der Linden, and C. E. Hanson, editors. Climate change 2007: impacts, adaptation and vulnerability. Contribution of Working Group II to the Fourth Assessment Report of the Intergovernmental Panel on Climate Change. Cambridge University Press, Cambridge, UK.

de Waal, A. 1997. Famine crimes: politics \& the disaster relief industry in Africa. African Rights, International African Institute, and Indiana University Press, Bloomington, Indiana, USA.

Dong, S., L. Wen, S. Liu, X. Zhang, J. P. Lassoie, S. Yi, X. Li, J. Li, and Y. Li. 2011. Vulnerability of worldwide pastoralism to global changes and interdisciplinary strategies for sustainable pastoralism. Ecology and Society 16(2): 10. [online \} URL: http ://www.ecologyandsociety.org/vol16/iss2/art10/.
Dougill, A. J., E. D. G. Fraser, J. Holden, K. Hubacek, C. Prell, M. Reed, S. Stagl, and L. Stringer. 2006. Learning from doing participatory rural research: lessons from the Peak District National Park. Journal of Agricultural Economics 57:259-275. http://dx.doi.org/10.1111/j.1477-9552 $.2006 .00051 . \mathrm{x}$

Dougill, A. J., E. D. G. Fraser, and M. S. Reed. 2010. Anticipating vulnerability to climate change in dryland pastoral systems: using dynamic systems models for the Kalahari. Ecology and Society 15(2): 17. [online] URL: http://www.ecologyandsociety.org/ vol15/iss2/art17/.

Dougill, A. J., D. Thomas, and A. Heathwaite. 1999. Environmental change in the Kalahari: integrated land degradation studies for non equilibrium dryland environments. Annals of the Association of American Geographers 89:420-442. http://dx.doi.o rg/10.1111/0004-5608.00156

Eakin, H. C., and M. B. Wehbe. 2009. Linking local vulnerability to system sustainability in a resilience framework: two cases from Latin America. Climatic Change 93:355-377. http://dx.doi.org/10.1007/s105 $\underline{\text { 84-008-9514-X }}$

Easterling, W., P. Aggarwal, P. Batima, K. Brander, L. Erda, S. Howden, A. Kirilenko, J. Morton, J.-F. Soussana, J. Schmidhuber, and F. Tubiello. 2007. Food, fibre and forest products. Pages 273-313 in M. L. Parry, O. F. Canziani, J. P. Palutikof, P. J. van der Linden, and C. E. Hanson, editors. Climate change 2007: impacts, adaptation and vulnerability. Contribution of Working Group II to the Fourth Assessment Report of the Intergovernmental Panel on Climate Change. Cambridge University Press, Cambridge, UK.

Epstein, J. 2008. Why model? Journal of Artificial Societies and Social Simulation 11(4):12. [online] URL: http://jasss.soc.surrey.ac.uk/11/4/12.html.

Ericksen, P. 2008. Conceptualizing food systems for global environmental change research. Global Environmental Change 18:234-245. http://dx.doi.o rg/10.1016/j.gloenvcha.2007.09.002

Fraser, E. D. G. 2003. Social vulnerability and ecological fragility: building bridges between social and natural sciences using the Irish Potato Famine as a case study. Conservation Ecology 7(2): 9. [online] URL: http://www.consecol.org/vol7/iss2/art9 
Fraser, E. D. G. 2006. Crop diversification and trade liberalization: linking global trade and local management through a regional case study. Agriculture and Human Values 23:271-281. http://d x.doi.org/10.1007/s10460-006-9005-5

Fraser, E. D. G. 2007. Travelling in antique lands: using past famines to develop an adaptability/ resilience framework to identify food systems vulnerable to climate change. Climatic Change 83:495-514. http://dx.doi.org/10.1007/s10584-0079240-9

Fraser, E. D. G., M. Termansen, N. Sun, D. Guan, E. Simelton, P. Dodds, K. Feng, and Y. Yu. 2008. Quantifying socioeconomic characteristics of drought sensitive regions: evidence from Chinese provincial agricultural data. Comptes Rendus Geosciences 340:679-688. http://dx.doi.org/10.1016/ j.crte.2008.07.004

Green, R. 1993. The political economy of drought in Southern Africa 1991-1993. Health Policy and Planning 8:256-266. http://dx.doi.org/10.1093/heap $\underline{\mathrm{o} l / 8.3 .256}$

Homer, J., and R. Oliva. 2001. Maps and models in system dynamics: a response to Coyle. System Dynamics Review 17:347-355. http://dx.doi.org/10 $.1002 / \mathrm{sdr} .224$

Hulme, M. 2007. Geographical work at the boundaries of climate change. Transactions of the Institute of British Geographers 33:5-11. http://dx. doi.org/10.1111/j.1475-5661.2007.00289.x

Intergovernmental Panel on Climate Change (IPCC). 2007a. Climate change 2007: the physical science basis. S. Solomon, D. Qin, M. Manning, M. Marquis, K. Averyt, M. M. B. Tignor, H. LeRoy Miller, Jr., Z. Chen, editors. Contribution of Working Group I to the Fourth Assessment Report of the Intergovernmental Panel on Climate Change. Cambridge University Press, Cambridge, UK.

Intergovernmental Panel on Climate Change (IPCC). 2007b. Climate change 2007: impacts, adaptation and vulnerability. M. Parry, O. Canziani, J. Palutikof, P. van der Linden, and C. Hanson, editors. Contribution of Working Group II to the Fourth Assessment Report of the Intergovernmental Panel on Climate Change. Cambridge University Press, Cambridge, UK.
Joubert, D. F., A. Rothauge, and G. N. Smit. 2008. A conceptual model of vegetation dynamics in the semiarid Highland savanna of Namibia, with particular reference to bush thickening by Acacia mellifera. Journal of Arid Environments 72:2201-2210. http://dx.doi.org/10.1016/j.jaridenv.2008.07.004

Lane, C. R. 1998. Custodians of the commons: pastoral land tenure in east and west Africa. Earthscan, London, UK.

Lane, D. 2007. The power of the bond between cause and effect: Jay Wright Forrester and the field of system dynamics. System Dynamic Review 23:95-118. http://dx.doi.org/10.1002/sdr.370

Li, W., and L. Huntsinger. 2011. China's grassland contract policy and its impacts on herder ability to benefit in Inner Mongolia: tragic feedbacks. Ecology and Society 16(2): 1. [online] URL: http:// www.ecologyandsociety.org/vol16/iss2/art1/.

Lioubimtseva, E., R. Cole, J. Adams, and G. Kapustin. 2005. Impacts of climate and land-cover changes in arid lands of Central Asia. Journal of Arid Environments 62:285-308. http://dx.doi.org/10 .1016/j.jaridenv.2004.11.005

Lobell, D. B., M. B. Burke, C. Tebaldi, M. D. Mastrandrea, W. P. Falcon, and R. L. Naylor. 2008. Prioritizing climate change adaptation needs for food security in 2030. Science 319:607-610. http:// dx.doi.org/10.1126/science.1152339

Máñez Costa, M. A., E. J. Moors, and E. Fraser. 2011. Socioeconomics, policy, or climate change: what is driving vulnerability in southern Portugal? Ecology and Society 16(1): 28. [online] URL: http: //www.ecologyandsociety.org/vol16/iss1/art28/.

Meadows, D. H., and Club of Rome. 1972. The limits to growth; a report for the Club of Rome's project on the predicament of mankind. Second edition. Signet, New York, New York, USA.

Mendelsohn, R. 2007. What causes crop failure? Climatic Change 81:61-70. http://dx.doi.org/doi:10 $.1007 / \mathrm{s} 10584-005-9009-\mathrm{y}$

Millennium Ecosystem Assessment. 2005. Ecosystems and human well-being: synthesis. Island Press, Washington, D.C., USA. 
Ostrom, E. 2001. Environment and common property institutions. Pages 4560-4566 in $\mathrm{H}$. Baltus and N. Smelser, editors. International encyclopedia of the social \& behavioral sciences. Elsevier Science, Oxford, UK.

Ostrom, E., J. Burger, C. Field, R. Norgaard, and D. Policansky. 1999. Revisiting the commons: local lessons, global challenges. Science 284:278-282. http://dx.doi.org/10.1126/science.284.5412.278

Quinn, C. H., G. Ziervogel, A. Taylor, T. Takama, and F. Thomalla. 2011. Coping with multiple stresses in rural South Africa. Ecology and Society 16(3): 2. http://dx.doi.org/10.5751/ES-04216-160302

Ravera, F., D. Tarrasón, and E. Simelton. 2011. Envisioning adaptive strategies to change: participatory scenarios for agropastoral semiarid systems in Nicaragua. Ecology and Society 16(1): 20. [online] URL: http://www.ecologyandsociety.org/ vol16/iss $1 /$ art $20 /$.

Reed, M. S., A. J. Dougill, and T. Baker. 2008. Participatory indicator development: what can ecologists and local communities learn from each other? Ecological Applications 18:1253-1269. http ://dx.doi.org/doi:10.1890/07-0519.1

Reynolds, J. F., D. M. Stafford Smith, E. F. Lambin, B. L. Turner, II, M. Mortimore, S. P. J. Batterbury, T. E. Downing, H. Dowlatabadi, R. J. Fernandez, J. E. Herrick, E. Huber-Sannwald, H. Jiang, R. Leemans, T. Lynam, F. T. Maestre, M. Ayarza, and B. Walker. 2007. Global desertification: building a science for dryland development. Science 316:847-851. http://dx.doi.org/10.1126/science.1131634

Richardson, G. 1986. Problems with causal-loop diagrams. System Dynamics Review 2:158-170. htt p://dx.doi.org/10.1002/sdr.4260020207

Roncoli, C., K. Ingram, and P. Kirshen. 2001. The costs and risks of coping with drought: livelihood impacts and farmers' responses in Burkina Faso. Climate Research 19:119-132. http://dx.doi.org/10. 3354/cr019119

Sallu, S. M., C. Twyman, and L. C. Stringer. 2010. Resilient or vulnerable livelihoods? Assessing livelihood dynamics and trajectories in rural Botswana. Ecology and Society 15(4): 3. [online]
URL: http://www.ecologyandsociety.org/vol15/iss4/ $\underline{\operatorname{art} 3 / .}$.

Scoones, I. 1998. Sustainable rural livelihoods: a framework for analysis. Institute of Development Studies, Brighton, UK.

Scott, W. R. 2001. Institutions and organizations. Foundation for Organizational Science. Second edition. Sage, Thousand Oaks, California, USA.

Sen, A. 1983. Poverty and famines. Claredon, Oxford, UK. http://dx.doi.org/10.1093/0198284632 .001 .0001

Sen, A. 2000. Development as freedom. Anchor, New York, New York, USA.

Sendzimir, J., C. P. Reij, and P. Magnuszewski. 2011. Rebuilding resilience in the Sahel: regreening in the Maradi and Zinder regions of Niger. Ecology and Society 16(3): 1. http://dx.doi.org/10.5751/ES04198-160301

Simelton, E., E. D. G. Fraser, M. Termansen, P. M. Forster, and A. J. Dougill. 2009. Typologies of cropdrought vulnerability: an empirical analysis of the socio-economic factors that influence the sensitivity and resilience to drought of three major food crops in China (1961-2001). Environmental Science and Policy 12:438-452. http://dx.doi.org/10.1016/j.envs ci.2008.11.005

Sitch, S., P. M. Cox, W. J. Collins, and C. Huntingford. 2007. Indirect radiative forcing of climate change through ozone effects on the landcarbon sink. Nature 448:791-794. http://dx.doi.org/ $\underline{10.1038 / \text { nature } 06059}$

Smit, B., and M. Skinner. 2002. Adaptation options in agriculture to climate change: a typology. Mitigation and Adaptation Strategies for Global Change 7:85-114. http://dx.doi.org/10.1023/A:101 $\underline{5862228270}$

Sterman, J. 1992. System dynamics modeling for project management. Sloan School of Management, Massachusetts Institute of Technology, Cambridge, Massachusetts, USA. [online] URL: http://web.mit. edu/jsterman/www/SDG/project.html.

Sterman, J. 2002. All models are wrong: reflections on becoming a systems scientist. System Dynamics Review 18:501-531. http://dx.doi.org/10.1002/sdr.261 
Stocking, M. A. 2003. Tropical soils and food security: the next 50 years. Science 302:1356-1359. http://dx.doi.org/10.1126/science.1088579

Stringer, L. 2008. Can the UN convention to combat desertification guide sustainable use of the world's soils? Frontiers in Ecology and the Environment 6:138-144. http://dx.doi.org/10.1890/070060

Suckall, N., E. D. G. Fraser, T. Cooper, and C. Quinn. 2009. Visitor perceptions of rural landscapes: a case study in the Peak District National. Journal of Environmental Management 90:1195-1203. http://dx.doi.org/10.1016/j.jenvman $\underline{.2008 .06 .003}$

Tansey, J., and T. O'Riordan. 1999. Cultural theory and risk: a review. Health, Risk and Society 1:71-90. http://dx.doi.org/10.1080/13698579908407008

Thomas, R. J. 2008. Opportunities to reduce vulnerability of dryland farmers in Central and West Asia and North Africa to climate change. Agriculture Ecosystems and Environment 126:36-45. http://dx.doi.org/10.1016/j.agee.2008.01.011

Thompson, J., and I. Scoones. 2009. Addressing the dynamics of agri-food systems: an emerging agenda for social science research. Environmental Science and Policy 12:386-397. http://dx.doi.org/10.1016/j. envsci.2009.03.001

Tompkins, E. 2005. Planning for climate change in small islands: insights from national hurricane preparedness in the Cayman Islands. Global Environmental Change 15:139-149. http://dx.doi.o rg/10.1016/j.gloenvcha.2004.11.002

Toulmin, C., and J. Quan. 2000. Evolving land rights, policy and tenure in Africa. Department for International Development Issues Series: International Institute for Environment and Development and Natural Resources Institute, London, UK.

Turner, B. L., R. E. Kasperson, P. A. Matson, J. J. McCarthy, R. W. Corell, L. Christensen, N. Eckley, J. X. Kasperson, A. Luers, M. L. Martello, C. Polsky, A. Pulsipher, and A. Schiller. 2003. A framework for vulnerability analysis in sustainability science. Proceedings of the National Academy of Sciences of the United States of America 100:8074-8079. http://dx.doi.org/10.1073/pnas.123 1335100
Unruh, J. 2001. The dilemma of African agrobiodiversity: Ethiopia and the role of food insecurity in conservation. Proceedings of the International Symposium Managing Biodiversity in Agricultural Ecosystems. People, Land Management and Environmental Change. The United Nations University (UNU/PLEC), Montreal, Quebec, Canada.

Van den Belt, M. 2004. Mediated modelling. Island Press, Washington D.C., USA.

Volpe, J., and C. Voss. 2005. Using dynamic system models for water use accountability and planning in Georgia. In K. J. Hatcher, editor. Proceedings of the 2005 Georgia Water Resources Conference. April 25-75, 2005, University of Georgia. Institute Ecology, The University of Georgia, Athens, Georgia, USA.

Watts, M., and H. Bohle. 1993. The space of vulnerability: the causal structure of hunger and famine. Progress in Human Geography 17:43-67.

Whiteside, M. 1998. Living farms: encouraging sustainable smallholders in southern Africa. Earthscan, London, UK.

Wolstenholme, E. 1999. Qualitative vs quantitative modelling: the evolving balance. Journal of the Operational Research Society 50:422-428. http://dx .doi.org/doi:10.2307/3010462

Wynne, B. 1992. Misunderstood misunderstanding: social identities and public uptake of science. Public Understanding of Science 1:281-304. http://dx.doi. org/10.1088/0963-6625/1/3/004 